\title{
Kontenery spawane ze stali Hardox 450 do transportu złomu i urobku skalnego
}

\author{
Welded containers for scrap and debris transport \\ of 450 Hardox steel
}

\section{Streszczenie}

W artykule przedstawiono zastosowanie stali Hardox 450 w budowie kontenerów. Podano właściwości mechaniczne stali w połączeniu z właściwościami technologicznymi i eksploatacyjnymi. Opisano możliwości kształtowania blach na zimno oraz jej spawalność. W końcowej części artykułu przedstawiono wybrane aspekty spawania stali Hardox 450. Dzięki zastosowaniu trudnościeralnej stali Hardox 450 uzyskano znacznie mniejszą masę kontenera w porównaniu z kontenerem wykonanym z powszechnie stosowanych stali o podwyższonej wytrzymałości.

Słowa kluczowe: właściwości stali Hardox 450, spawalność, spawanie stali Hardox, budowa kontenerów

\section{Abstract}

This article presents an application of Hardox 450 in the construction of containers. Given the mechanical properties of the steel in combination with technological and operational characteristics. Described the possibility of cold metal forming and its weldability. In the final part of the paper presents some aspects of welding Hardox 450. Thanks to the wear-resistant Hardox 450 is a reduction in the weight of the container, compared with a container made of commonly used high-strength steels.

Keywords: Hardox 450 properties, weldability, Hardox steel welding, construction container

\section{Wstęp}

Huty szwedzkiej grupy SSAB produkują stale do wielu gałęzi przemysłu, koncentrując się jednakże na stalach wysokowytrzymałych do kształtowania na zimno. Stąd przy produkcji stali obszarami priorytetowymi są: skład chemiczny, w tym możliwie mała zawartość węgla, kontrolowana wielkość ziarna oraz w półfabrykatach: ścisłe tolerancje grubości, płaskość, wykończenie powierzchni i niskie naprężenia wewnętrzne. Zasadniczo, stali wyprodukowanej w SSAB używa się w celu eliminacji procesu obróbki cieplnej, zwiększenia żywotności produktu i jego bezpieczeństwa a także obniżenia masy i kosztów produkcji.

Najbardziej znanym producentem wysokiej jakości blach trudnościeralnych jest szwedzka huta SSAB Oxelösund $A B$. Blachy z tej huty dostarczane są pod handlową nazwą Hardox. Hardox jest stalą przeznaczoną do zastosowań, gdzie pożądane jest uzyskanie dużej odporności na ścieranie $\mathrm{w}$ połączeniu z podatnością do przeróbki plastycznej na zimno i spawalnością [1,2].

Jedną z propozycji dotyczącej zastosowania stali Hardox 450, stanowiącej cel niniejszego opracowania, jest budowa spawanych kontenerów, szczególnie z przeznaczeniem do transportu złomu i urobku skalnego.

\section{Właściwości stali Hardox 450}

Stal Hardox 450 charakteryzuje się wysoką odpornością na zużycie ścierne, możliwością gięcia i obróbki skrawaniem specjalistycznymi narzędziami oraz stosunkowo dobrą spawalnością. Dzięki takim właściwościom, jak: wysokie właściwości mechaniczne i odporność na obciążenia udarowe, w tym odporność na wgniecenie, stal znajduje szerokie zastosowanie $w$ budowie ciężkich maszyn budowlanych, górnictwie, transporcie, m.in. w budowie kontenerów [3,4].

Skład chemiczny stali Hardox 450 zamieszczono w tablicy I natomiast właściwości mechaniczne w tablicy II.

Unikatowe zestawienie udarności na poziomie blach konstrukcyjnych zwykłej jakości i drobnoziarnistych z wysoką wytrzymałością i odpornością na ścieranie, Hardox 450 stanowi pożądany materiał do produkcji kontenerów przeznaczonych do transportu złomu i urobku skalnego. Granica plastyczności tej stali na poziomie $1200 \mathrm{MPa}$, umożliwia eksploatację kontenerów również przy dużych gabarytowo skałach, bez dużego ryzyka powstawania pęknięć. Wysoka udarność stali gwarantuje większe bezpieczeństwo pracy niż w przypadku kontenerów wykonanych z innych gatunków stali.

Wąska tolerancja twardości (425-475 HBW) umożliwia

Prof. dr hab. inż. Zbigniew Mirski - Politechnika Wrocławska, mgr inż. Zbigniew Fałek - Biuro Projektowo-Badawcze MIFA-Projekt Oława. 
jednorodną odporność na zużycie ścierne. Np. przy transporcie urobku granitowego badania odporności na ścieranie wykazały wzrost żywotności o $80 \%$ w porównaniu ze stalami o twardości 400 HBW [2]. Zawężenie tolerancji grubości blachy ze stali Hardox 450, w porównaniu z innymi gatunkami stali, daje w budowie kontenera oszczędności rzędu kilkudziesięciu kilogramów blachy.

W ramach grupy kapitałowej SSAB przeprowadzono szereg badań niszczących i eksploatacyjnych kontenerów hakowych, wykonanych ze stali Hardox 450. Ważnym parametrem pracy blach stosowanych na kontenery hakowe jest odporność na wgniecenia. Test polegający na zrzuceniu ciężaru o masie 300 kg z wysokości 2,85 m wykazał znacznie większą odporność na wgniecenia i uderzenia blachy ze stali Hardox 450 o wymiarach $600 \times 600 \times 16$ mm w porównaniu z blachą ze stali 355 (rys. 1). Głębokość wgniecenia dla blachy ze stali Hardox 450 wyniosła ok. $8 \mathrm{~mm}$ i była ponad 3-krotnie mniejsza w porównaniu ze stalą o podwyższonej wytrzymałości.

Połączenie wysokiej twardości i wytrzymałości mechanicznej pozwala na zastosowanie nowego podejścia przy projektowaniu kontenerów ze stali Hardox. Mała ilość belek wzmacniających, poprzeczek i wsporników w strukturze nośnej kontenera oraz możliwość zastosowania cieńszych blach, zwiększa zdolności załadunkowe. Kontener bez zewnętrznych elementów wzmacniających charakteryzuje się lepszą aerodynamiką, co skutkuje zmniejszonym zużyciem paliwa przez pojazd transportujący.

Tablica I. Skład chemiczny i równoważniki węgla stali Hardox 450 w zależności od grubości blachy $[1,2,6]$

Table I. Chemical composition and carbon equivalents Hardox 450, depending on the thickness of the sheet metal $[1,2,6]$

\begin{tabular}{|c|c|c|c|c|c|c|}
\hline \multicolumn{2}{|c|}{$\begin{array}{l}\text { Grubość blachy } \\
\text { [mm] }\end{array}$} & $3-8$ & (8) - 20 & $(20)-40$ & $(40)-50$ & \multirow{2}{*}{$\begin{array}{c}(50)-80 \\
0,26\end{array}$} \\
\hline $\mathrm{C}$ & \multirow{9}{*}{$\begin{array}{l}\max \\
\% \text { wag. }\end{array}$} & \multicolumn{2}{|c|}{0,21} & \multicolumn{2}{|c|}{0,23} & \\
\hline Si & & \multicolumn{5}{|c|}{0,7} \\
\hline $\mathrm{Mn}$ & & \multicolumn{5}{|c|}{1,60} \\
\hline$P$ & & \multicolumn{5}{|c|}{0,025} \\
\hline S & & \multicolumn{5}{|c|}{0,01} \\
\hline $\mathrm{Cr}$ & & 0,25 & 0,5 & 1,0 & \multicolumn{2}{|c|}{1,4} \\
\hline $\mathrm{Ni}$ & & \multicolumn{4}{|c|}{0,25} & 1,0 \\
\hline Mo & & \multicolumn{3}{|c|}{0,25} & \multicolumn{2}{|c|}{0,6} \\
\hline B & & \multicolumn{5}{|c|}{0,004} \\
\hline CEV & \multirow{2}{*}{$\%$} & 0,41 & 0,47 & 0,57 & 0,59 & 0,72 \\
\hline CET & & 0,3 & 0,34 & 0,37 & 0,36 & 0,41 \\
\hline \multicolumn{7}{|c|}{$C E V=\frac{M n}{6}+\frac{M o+C r+V}{6}+\frac{N i+C u}{15}$} \\
\hline
\end{tabular}

Przeprowadzone własne badania numeryczne wykazały, że zastępując blachę ze stali S355 blachą Hardox 450 można się spodziewać, w zależności od pojemności kontenera, redukcji jego masy nawet do $25 \%$. Wg danych SSAB, zastosowanie stali Hardox 450 na kontenery, pozwala też na kilkakrotne wydłużenie okresu ich eksploatacji w porównaniu z kontenerami wykonanymi z powszechnie stosowanych stali konstrukcyjnych [2].

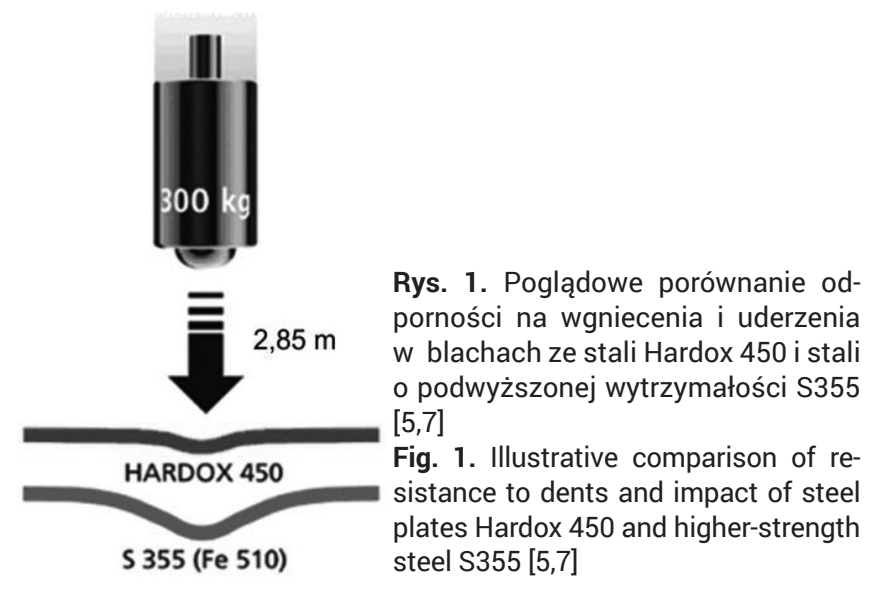

\section{Podatność na gięcie}

Ważną właściwością w budowie kontenerów jest przydatność stali do przeróbki plastycznej. Siła gięcia oraz skumulowane naprężenia sprężyste zwiększają się wraz ze wzrostem wytrzymałości blachy. Im blacha jest twardsza i wytrzymalsza, tym większa jest wymagana siła i promień gięcia. Dla stali Hardox 450 zaleca się gięcie blachy przygotowanej fabrycznie tj. śrutowanej oraz pokrytej powłoką antykorozyjną. Uszkodzenia powierzchni blachy oraz obecność korozji na powierzchni zginanej mogą obniżyć jej plastyczność. W szczególnych przypadkach takie defekty blachy należy usunąć. Przycięte krawędzie należy zeszlifować [5].

\section{Cięcie}

Do blach ze wszystkich stali Hardox możliwe jest zastosowanie takich metod cięcia, jak: cięcie tlenowe, plazmowe, laserowe i strugą wodną z cząstkami ściernymi. Cięcie tlenowe blachy o grubości do $40 \mathrm{~mm}$ ze stali Hardox 450 nie wymaga podgrzewania wstępnego. Nie zaleca się cięcia mechanicznego tej blachy ze względu na jej znaczną twardość.

Cięcie tlenowe cienkich blach ze stali Hardox jest równie łatwe jak cięcie stali niestopowych. Jednakże cięcie grubszych blach jest już trudniejsze. Jest to spowodowane możliwością powstania pęknięć przy krawędziach cięcia. Ujawniają się one jako pęknięcia zwłoczne w czasie od 48 godzin nawet do kilku tygodni po wykonaniu cięcia. Ryzyko wystąpienia pęknięć wzrasta wraz ze zwiększaniem się twardości stali oraz grubości ciętej blachy.

Tablica II. Właściwości mechaniczne stali Hardox 450 dla blachy o grubości 20 mm [3,6,7]

Table II. Mechanical properties of Hardox 450 for sheet metal thicknesses of $20 \mathrm{~mm}[3,6,7]$

\begin{tabular}{|c|c|c|c|c|}
\hline $\begin{array}{c}\text { Twardość } \\
\text { HBW }\end{array}$ & $\begin{array}{c}\text { Granica } \\
\text { plastyczności } \\
\mathrm{R}_{\mathrm{e}^{\prime}}[\mathrm{MPa}]\end{array}$ & $\begin{array}{c}\text { Wytrzymałość } \\
\text { na rozciąganie } \\
\mathrm{R}_{\mathrm{m}^{\prime}}[\mathrm{MPa}]\end{array}$ & $\begin{array}{c}\text { Wydłużenie względne } \\
\mathrm{A}_{5^{\prime}}[\%]\end{array}$ & $\begin{array}{c}\text { Praca łamania** } \\
\text { Charpy-V, }[\mathrm{J}]\end{array}$ \\
\hline $425-475$ & 1200 & 1400 & 10 & 40 \\
\hline $\begin{array}{l}\text { * twardość zgodnie z PN-EN ISO } 6506-1: 2014-12-\text { mierzona na powierzchni obrobionej mechanicznie na głębokość } 0,5-2 \mathrm{~mm} \\
\text { **wzdłuż kierunku walcowania w temperaturze }-40{ }^{\circ} \mathrm{C}\end{array}$
\end{tabular}


Ewentualnych pęknięć można uniknąć przez:

- podgrzewanie wstępne, wytyczne w tablicy III,

- podgrzewanie elementów zaraz po zakończeniu cięcia,

- zmniejszenie prędkości cięcia,

- powolne chłodzenie po cięciu.

Jeśli podgrzewanie wstępne nie zostanie przeprowadzone, maksymalna dopuszczalna prędkość cięcia zależy od grubości blachy (tabl. III).

Tablica III. Zalecana temperatura podgrzewania wstępnego do cięcia tlenowego stali Hardox 450 oraz prędkość cięcia bez podgrzewania [5]

Table III. Recommended preheat temperature for cutting oxygen Hardox 450 and cutting speed without heating [5]

\begin{tabular}{|c|c|c|c|c|c|c|}
\hline $\begin{array}{c}\text { Grubość materiału } \\
{[\mathrm{mm}]}\end{array}$ & $<40$ & $<45$ & $<50$ & $<60$ & $<70$ & $<80$ \\
\hline $\begin{array}{c}\text { Temperatura } \\
\left.\text { podgrzewania [ }{ }^{\circ} \mathrm{C}\right]\end{array}$ & \multicolumn{2}{|c|}{100} & \multicolumn{2}{|c|}{150} & \multicolumn{2}{|c|}{175} \\
\hline $\begin{array}{c}\text { Prędkość cięcia } \\
\text { bez podgrzewania } \\
\text { wstępnego [mm/min] }\end{array}$ & 230 & 200 & 180 & 170 & 160 & 150 \\
\hline
\end{tabular}

Powolne chłodzenie zmniejsza ryzyko powstawania pęknięć przy krawędziach cięcia blachy. Można je osiągnąć po zakończeniu cięcia, gdy jeszcze ciepłe elementy zostaną ułożone na stosie i przykryte kocem izolacyjnym. Elementy powinny schłodzić się do temperatury otoczenia.

Nagrzewanie elementów zaraz po zakończeniu cięcia jest również skuteczne. Wydłuża ono czas uwalniania się wodoru ze strefy ciętego materiału oraz sprzyja relaksacji naprężeń na ciętych powierzchniach blachy. Do tego celu stosuje się elektryczne maty ogrzewające, palniki gazowe lub piece.

W celu wyraźnego zredukowania strefy wpływu ciepła przy krawędzi ciętego materiału cięcie tlenowe należy zastąpić cięciem plazmowym lub laserowym.

Najskuteczniejszym sposobem eliminującym strefę wpływu ciepła i ryzyko powstawania pęknięć, jest zastosowanie cięcia za pomocą strugi wodnościernej.

\section{Spawalność stali Hardox}

Ogólnie stale Hardox uznawane są jako dobrze spawalne. Hardox 450 jest stalą o małej zawartości węgla i dodatków stopowych, co w praktyce oznacza niski równoważnik węgla (dla blachy o grubości do $8 \mathrm{~mm} \mathrm{CEV=0,41 \% ).} \mathrm{Mogą} \mathrm{więc} \mathrm{być}$ łączone przy zastosowaniu każdej konwencjonalnej metody spawania łukowego, stosowanej powszechnie do spawania niskowęglowych stali niestopowych.

W ujęciu ogólnym spawalność stali Hardox uwarunkowana jest:

- temperaturą podgrzewania i temperaturą międzyściegową,

- doprowadzanym ciepłem do powstającego złącza,

- rodzajem materiałów dodatkowych,

- gazem osłonowym,

- rozmiarem odstępu i ukosowaniem krawędzi blach,

- kolejnością układania ściegów.

Temperatura podgrzewania stali Hardox 450 przy energii

liniowej spawania $1,7 \mathrm{~kJ} / \mathrm{mm}$ powinna wynosić $[1,5]$ :

- dla blachy o grubości $<20-40 \mathrm{~mm}-125^{\circ} \mathrm{C}$,

- dla blachy o grubości $<40-80 \mathrm{~mm}-150^{\circ} \mathrm{C}$.

Temperatura międzyściegowa nie powinna przekraczać $225^{\circ} \mathrm{C}$ aby nie spowodować znacznego spadku twardości złącza spawanego.

Przy wysokiej wilgotności powietrza oraz w temperaturze otoczenia poniżej $5{ }^{\circ} \mathrm{C}$, podane temperatury podgrzewania należy zwiększyć o $25^{\circ} \mathrm{C}$.
Temperaturę podgrzewania i międzyściegową należy mierzyć dla blachy o największej grubości. Jeśli blacha ma grubość $25 \mathrm{~mm}$, temperaturę należy zmierzyć 2 minuty po podgrzaniu. Temperaturę międzyściegową można mierzyć dla metalu spoiny lub bezpośrednio dla materiału z nim sąsiadującego - rysunek 2 .

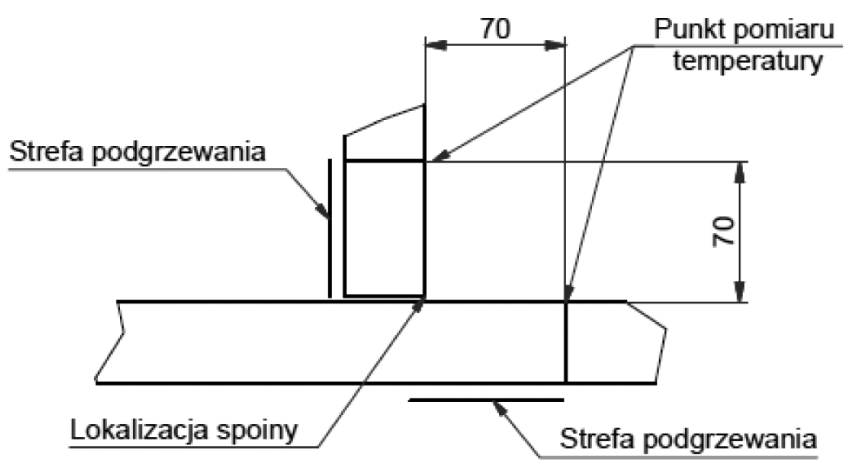

Rys. 2. Miejsca temperatury podgrzewania i pomiaru temperatury międzyściegowej przy spawaniu elementów ze stali Hardox 450

Fig. 2. Place the heating temperature and interpass temperature measurement in welding parts Hardox 450

Zalecenia dotyczące temperatury podgrzewania i międzyściegowej mają również zastosowanie do spoin sczepnych i ściegów graniowych. Długość spoin sczepnych powinna wynosić co najmniej 50 mm, przy wykonywaniu długich połączeń w konstrukcji kontenera.

Spawanie przy zalecanym doprowadzeniu ciepła ma znaczący wpływ na właściwości złącza. Jeśli spoina łączy blachy o różnej grubości, zalecana ilość doprowadzanego ciepła dotyczy cieńszej blachy.

Maksymalną ilość ciepła doprowadzonego przy spawaniu stali Hardox przedstawiono na rysunku $3[1,5]$.

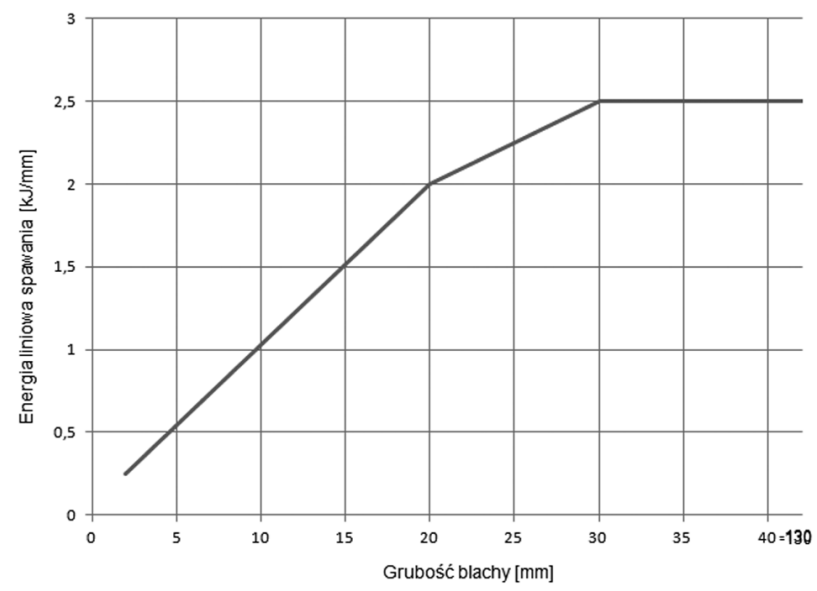

Rys. 3. Maksymalna energia liniowa przy spawaniu stali Hardox w zależności od grubości blachy [1,5]

Fig. 3. Maximum heat input welding Hardox steel depending on the thickness of the sheet metal $[1,5]$

Przy spawaniu stali Hardox elektrodami otulonymi, należy stosować przede wszystkim elektrody rutylowe, o zawartości wodoru w stopiwie poniżej $5 \mathrm{ml} / 100 \mathrm{~g}$ [1]. Należy przy tym używać elektrod miękkich (granica plastyczności poniżej $500 \mathrm{MPa}$ ). Elektrody takie zmniejszają poziom naprężeń własnych w połączeniu spawanym i tym samym jej podatność na pękanie w obniżonych temperaturach. Tak niską zawartość wodoru w spoinie zapewnia również spawanie drutem litym metodami MAG, MIG i TIG.

Materiały dodatkowe ze stali austenitycznej Cr-Ni mogą być z powodzeniem zastosowane do spawania stali Hardox 450 w temperaturze pokojowej $\left(+20^{\circ} \mathrm{C}\right)$, bez wstępnego podgrzewania. Mają one również zastosowanie także jako 
warstwy buforowe przed nakładaniem ostatniej utwardzającej warstwy wypełniającej spoin narażonych na intensywne zużycie ścierne - rysunek 4 [1,5].

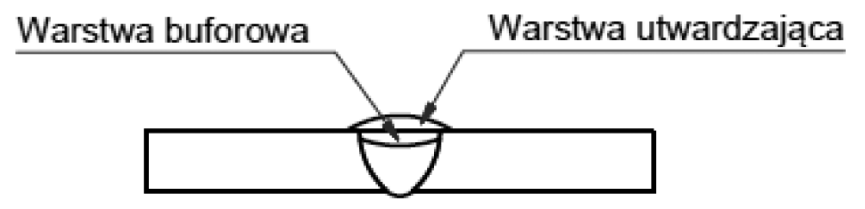

Rys. 4. Nakładanie warstwy buforowej i ostatniej warstwy utwardzającej przy spawaniu blachy ze stali Hardox 450

Fig. 4. Application of the buffer layer and the last layer of hardening sheet metal welding Hardox 450

Przy spawaniu w osłonie gazów, wybór odpowiedniej mieszanki zależy od rodzaju procesu technologicznego spawania. Przykładowe mieszanki gazowe stosowane przy spawaniu stali Hardox zestawiono w tablicy IV.

Przygotowanie krawędzi blach do spawania należy wykonać wg PN-EN ISO 9692-1:2014-2. Poprawnie wykonane złącza wykazują wytrzymałość wyższą niż wytrzymałość stali konstrukcyjnej drobnoziarnistej - nawet powyżej $700 \mathrm{MPa}$, jednak w strefie wpływu ciepła - pomimo ograniczenia ilości ciepła wprowadzonego do spoiny - obserwuje się spadek twardości nawet do poziomu $50 \%$ w porównaniu ze stanem dostawy (odmiennie niż przy spawaniu stali konstrukcyjnych wg PN-EN 10025-6+A1:2009).

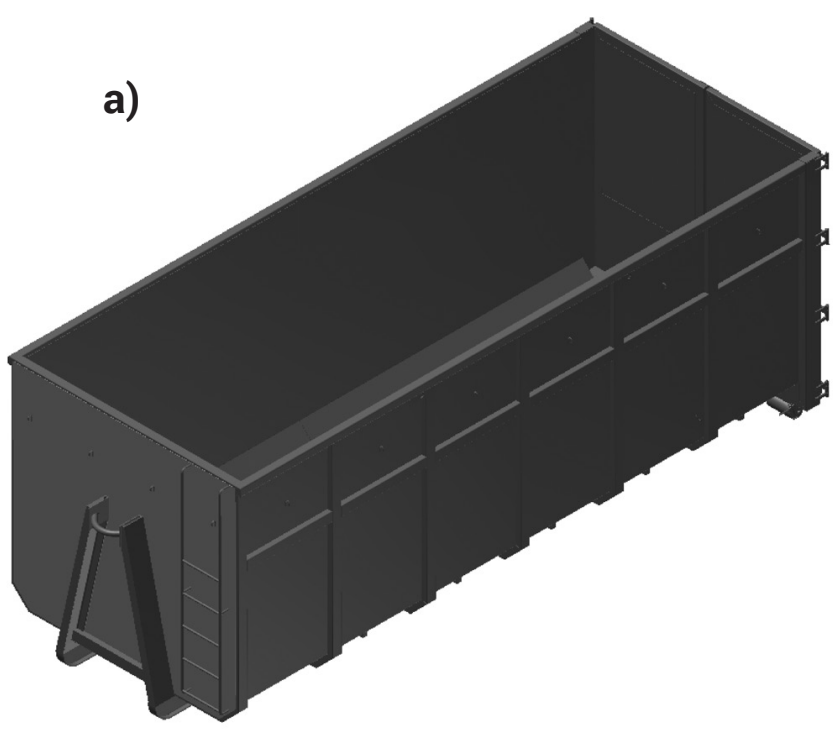

\section{Kontener hakowy ze stali Hardox 450}

Aktualnie do budowy kontenerów hakowych przeznaczonych do transportu złomu, gruzu i urobku skalnego (rys. 5a i 5b), spełniających wymagania normy DIN-EN 30722, stosuje się materiały spełniające przede wszystkim wymagania wytrzymałościowe.

Parametry kontenera hakowego (rys. 5):

- pojemność - $30 \mathrm{~m}^{3}$,

- materiał szkieletu - S235JRG2,

- materiał oblachowania-S355J2G3,

- masa całkowita kontenera (rys. 5a) - $2930 \mathrm{~kg}$,

- masa szkieletu (rys. 5b) - $1430 \mathrm{~kg}$

- masa oblachowania - $1500 \mathrm{~kg}$.

Nie zapewniają one jednak oczekiwanej trwałości. Już po kilkuletnim okresie eksploatacji przy transporcie złomu i kruszyw, stopień destrukcji poprzez odkształcenia, wybrzuszenia, deformację oblachowania jest tak poważny, że dalsza ich eksploatacja staje się niemożliwa a naprawa kontenera często nieopłacalna.

Trwałość kontenerów można zwiększyć kilkakrotnie zastępując blachy konstrukcyjne na elementy ścian oraz podłóg trudnościeralnymi blachami ze stali Hardox 450. Na struktury nośne kontenera należy zastosować stal o wyższej wytrzymałości np. S355. Na kontenery o pojemności $30 \mathrm{~m}^{3}$ wystarczające jest zastosowanie blachy o grubości

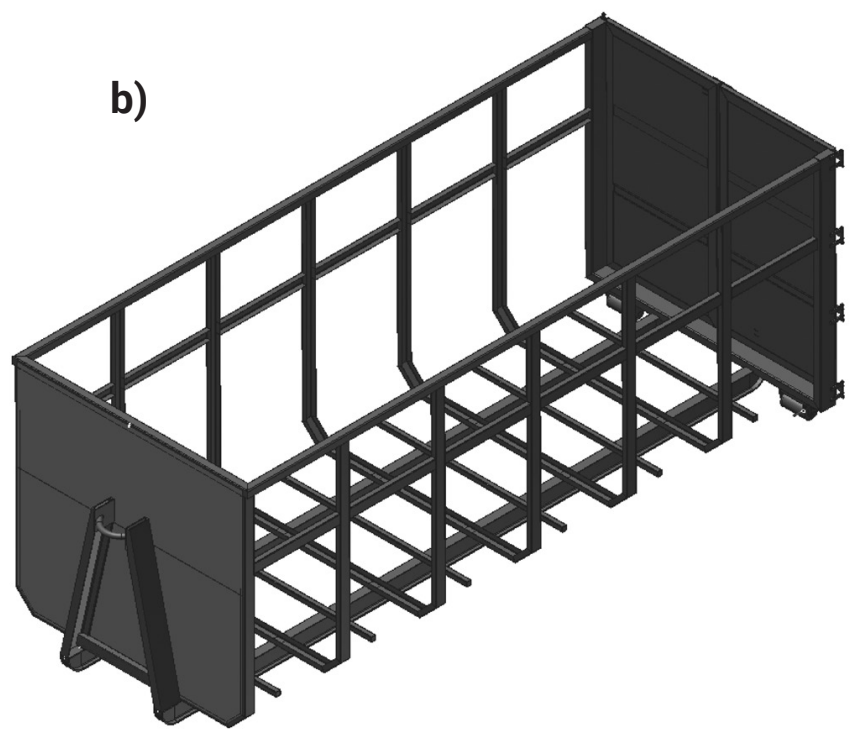

Rys. 5. Typowa konstrukcja kontenera hakowego o pojemności $30 \mathrm{~m}^{3}$ : a) widok perspektywiczny kontenera, b) widok perspektywiczny szkieletu kontenera

Fig. 5. Typical structure of the hook of the container with a capacity of $30 \mathrm{~m}^{3}:$ a) perspective view of the container, b) perspective view of the skeleton of the container

Tablica IV. Przykładowe mieszanki gazowe stosowane przy spawaniu stali Hardox $[1,5]$

Table IV. Examples of gas mixtures used in welding Hardox [1,5]

\begin{tabular}{|l|l|l|}
\hline \multicolumn{1}{|c|}{ Metoda spawania } & \multicolumn{1}{|c|}{ Rodzaj tuku } \\
\hline $\begin{array}{l}\text { MAG, drut lity } \\
\text { MAG drut proszkowy }\end{array}$ & zwarciowy & $\mathrm{Ar}+15-25 \% \mathrm{CO}_{2}$ \\
\hline $\begin{array}{l}\text { MAG, drut lity } \\
\text { MAG drut proszkowy }\end{array}$ & natryskowy \\
\hline MAG, drut proszkowy & zwarciowy & $\mathrm{Ar}+8-25 \% \mathrm{CO}_{2}$ \\
\hline MAG, drut proszkowy & natryskowy & $\mathrm{Ar}+15-25 \mathrm{CO}_{2} \mathrm{lub} \mathrm{CO}_{2}$ \\
\hline MAG, wszystkie rodzaje & zwarciowy lub natryskowy & $\mathrm{Ar}+8-25 \% \mathrm{CO}_{2}$ \\
\hline TIG & & $\mathrm{Ar}+15-25 \% \mathrm{CO}_{2}$ \\
\hline
\end{tabular}


$4 \mathrm{~mm}$ na podłogę oraz na elementy ścian - 3,2 mm. Dzięki zastosowaniu stali Hardox można projektować kontenery przy zastosowaniu minimalnej liczby zewnętrznych wzmocnień.

Kontenery ze stali Hardox znalazły zastosowanie do transportu złomu, urobku skalnego, piasku, węgla, kopalin itp. Wytrzymałość i trwałość oraz odporność na ścieranie i odkształcenia stali Hardox, zapewnia niezawodność oraz ochronę przed zużyciem w czasie całego okresu eksploatacji kontenera oraz pozwala na zastosowanie dużo cieńszych blach przy jego wytwarzaniu. Na podstawie własnych obliczeń pracochłonność wykonania takiego kontenera zmniejsza się o ok. 23\% (oszacowano na podstawie czasu wykonania wyeliminowanych części, występujących w kontenerze wykonanym z powszechnie stosowanych stali konstrukcyjnych).

Dla użytkowników wyższy koszt inwestycji jest równoważony przez oszczędności długoterminowe ze względu na niższe koszty utrzymania, eksploatacji i transportu wsadu o większej masie - równoważonej lżejszym kontenerem.
Na rysunku 6a i 6b przedstawiono model kontenera, spełniającego wymagania normy DIN-EN 30722, w którym blachy konstrukcyjne na elementy ścian oraz podłogi zastąpiono trudnościeralną blachą ze stali Hardox 450.

Osiągnięte parametry kontenera hakowego oblachowanego stalą Hardox 450, przedstawionego na rysunku 6, są następujące:

- pojemność - $30 \mathrm{~m}^{3}$,

- materiał szkieletu - S355JRG2,

- materiał oblachowania - Hardox 450,

- masa całkowita kontenera (rys. 6a) - $2200 \mathrm{~kg}$,

- masa szkieletu (rys. 6b) - 950 kg,

- masa oblachowania - $1250 \mathrm{~kg}$.

Badania niszczące i eksploatacyjne kontenerów ze stali Hardox 450 wykonane w ramach grupy kapitałowej SSAB, w pełni potwierdzają zasadność stosowania tej stali na kontenery do transportu złomu i urobku skalnego, w tym skał wielkogabarytowych.
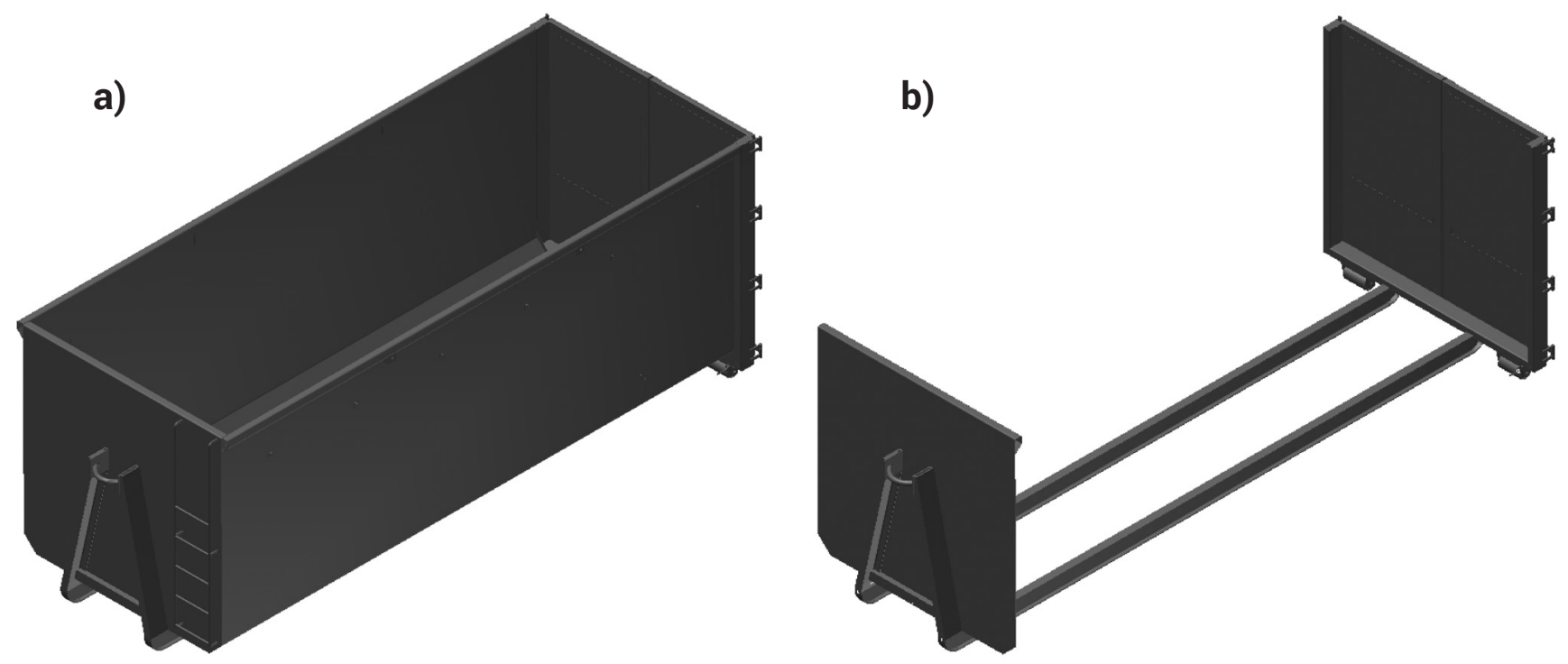

Rys. 6. Model kontenera hakowego o pojemności $30 \mathrm{~m}^{3}$ : a) widok perspektywiczny kontenera-oblachowanie ścian i podłogi ze stali Hardox 450 , b) widok perspektywiczny szkieletu kontenera ze stali S355

Fig. 6. Hook container with a capacity of $30 \mathrm{~m}^{3}$ : a) container - flashings perspective view of the walls and floors of Hardox 450 , b) perspective view of the container skeleton of steel S355

\section{Podsumowanie}

1. Kontener z blachy Hardox 450 wykazuje wysoką odporność na wszelkiego rodzaju działania destrukcyjne.

2. Kontener hakowy o pojemności $30 \mathrm{~m}^{3}$, wykonany z blachy Hardox 450, jest lżejszy od analogicznego kontenera wykonanego z blachy S355J2G3 o ok. $730 \mathrm{~kg}$.

3. Pracochłonność wykonania kontenera hakowego o pojemności $30 \mathrm{~m}^{3}$ z blachy ze stali Hardox 450 jest niższa o ok. $23 \%$ od analogicznej pracochłonności dotyczącej kontenera wykonanego z powszechnie stosowanych stali konstrukcyjnych.

\section{Literatura}

[1] SSAB: Welding Hardox and Weldox, Oxelösund, Sweden.

[2] http://www.hardox.com/

[3] Konat Ł.: Struktury i właściwości stali Hardox a ich możliwości aplikacyjne w warunkach zużywania ściernego i obciążeń dynamicznych, Rozprawa doktorska, Wydział Mechaniczny Politechniki Wrocławskiej, Wrocław 2007.

[4] Cegiel L., Konat Ł., Pawłowski T., Pękalski G.: Stale Hardox - nowe generacje materiałów konstrukcyjnych maszyn górnictwa odkrywkowego, Węgiel Brunatny, nr 3/56, 2006.
[5] http://www.hardox.com/pl//nformacje-na-temat-Hardox/ Przegld/.

[6] http://www.hardox.com/pl/Informacje-na-temat-Hardox/ Wlasnosci/.

[7] Stal-Hurt: Hardox 450 - Trwałe blachy trudnościeralne - katalog, Marciszów. 